\title{
A model of the novel concept liquid piston engine sourced by waste heat
}

\author{
Wojciech Bujalski ${ }^{1}$, Kamil Futyma², Jarosław Milewski ${ }^{3}$ and Arkadiusz Szczęśniak**4 \\ ${ }^{1}$ Warsaw University of Technology, Institute of Heat Engineering, Nowowiejska 21/25, 00-665 Warszawa \\ ${ }^{2}$ Warsaw University of Technology, Institute of Heat Engineering, Nowowiejska 21/25, 00-665 Warszawa \\ ${ }^{3}$ Warsaw University of Technology, Institute of Heat Engineering, Nowowiejska 21/25, 00-665 Warszawa \\ ${ }^{4}$ Warsaw University of Technology, Institute of Heat Engineering, Nowowiejska 21/25, 00-665 Warszawa
}

\begin{abstract}
This paper describes the model of the novel concept liquid piston engine, which is designed to convert low-grade waste heat into electricity. The proposed dynamic oriented model is implemented in Aspen Hysys that enables simulations dynamic simulation of various working agents. The simulation results were verified with experimental data obtained from the research installation. The proposed model demonstrated relatively small discrepancies with respect to experimental research, hence it could be used as a tool for research on optimization of an innovative power plant operation, i.e. various working agents, various operating pressures.
\end{abstract}

\section{Introduction}

Nowadays, energy becomes more and more expensive what drives a research on new innovative power systems e.g system based on fuel cells [1], electrolysis combined with turbines [2,3], compressed air energy storage $[4,5]$ etc). One of the promising sources of power is an utilization of low-grade waste heat, which is being released into the environment. In addition, the utilization of waste heat could lead to reduction of fossil fuel consumption and alleviating environmental problems.

The promising concept for waste recovery seems to be an liquid piston engine, which is recognized as a type of Stirling engine [6]. The concept of liquid piston engine was firstly reported in the available literature in 1971 and denoted as Fluidyne engine [7]. Together with the basic system layout, the several modifications were proposed [8-10]. Slavin et al. [8] proposed a new scheme of engine that is characterized by use of offset heat exchangers instead of the usual heater and cooler. The system layout was firstly reported by [9]. In addition, Author [8] developed numerical model and simulated engine working cycle to define characteristic parameters for system design. Author concluded that the energy conversion based on the proposed principle is a promising area, however he [8] indicated that the realization of the prosed scheme is debatable due to difficulties related to its construction such as requirements for valves related to short actuation period, the realization of components sealing such as hydroturbine.

We proposed the novel concept of fluid piston engine called "TURMES" [11], where the vapor of low-boiling fluids expands inside the tank and forces a flow of liquid to ensure a continuous liquid flow through the expander - see Fig 1.

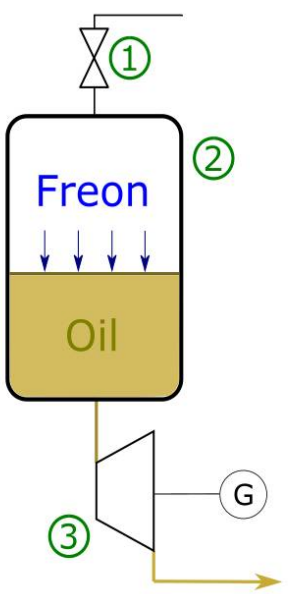

Fig. 1. General idea of the proposed concept TURMES; $1-$ valve, 2 - pressurized tank, 3 - oil expander.

The proposed system was constructed in lab-scale $(1 \mathrm{~kW}$ power installation) and used for model validation. The prelimary study [12-14] revealed that the most suitable pair of working agents with respect to operating conditions are vapor of R-245fa and oil: Ergolid A selected parameters of working agents are displayed in table 1.

\footnotetext{
* Corresponding author: Arkadiusz.szczesniak@itc.pw.edu.pl
} 
Table 1. Setting Word's margins.

\begin{tabular}{|c|c|}
\hline Property & Value \\
\hline Freon & \\
\hline Trade name & R-245fa \\
\hline CAS Number & $460-73-1$ \\
\hline Liquid working agent & \\
\hline Trade name & $\begin{array}{c}\text { Ergolid A (- } \\
\left.35^{\circ}\right)\end{array}$ \\
\hline CAS Number & $107-21-1$ \\
\hline$\%$ concentration of glycol & 48 \\
\hline Type of glycol & ethylene \\
\hline
\end{tabular}

\section{Working principle of the proposed concept of liquid piston engine}

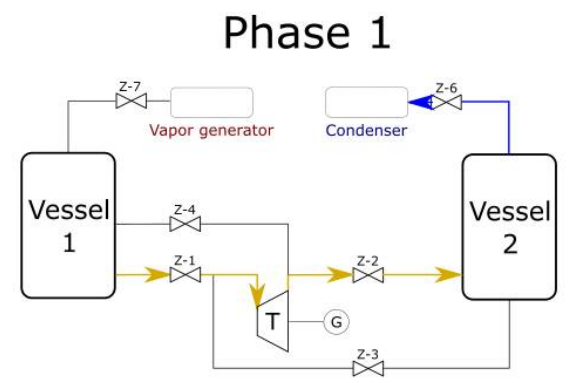

Phase 2

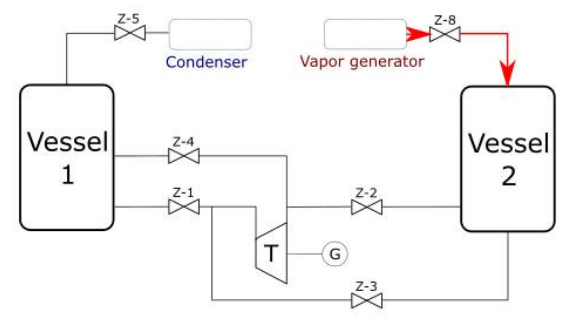

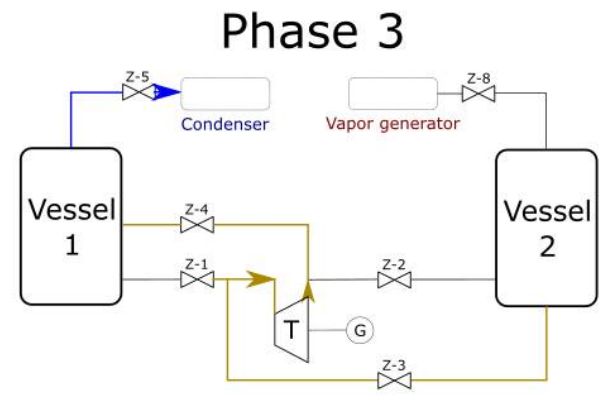

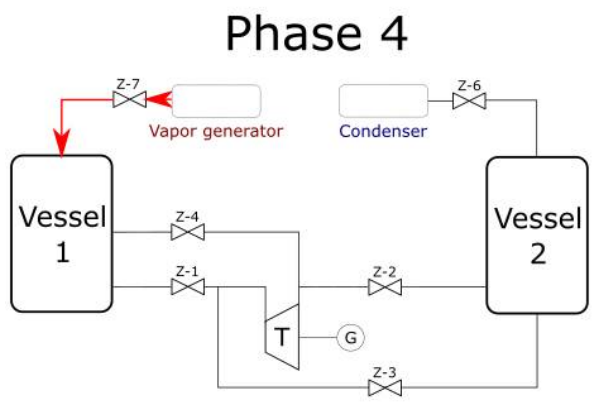

Fig 2: Simplified diagram the innovating power plant equipped with liquid turbine and hydraulic-gas generator of working agent's flow, sources by waste heat

The working principle of novel concept liquid piston engine is guided by opening and closing valves that are used to control the process of oil and liquid motion. In general, the four operation modes are distinguished at liquid piston operation (see Fig. 2):

- Phase 1 - freon expands inside the vessel 1 and forces the flow of Ergolid, which drives a turbine. Valve $\mathrm{Z} 1$ and $\mathrm{Z} 2$ are opened. Valve Z3 and $\mathrm{Z} 4$ are closed

- Phase 2 - when the pressure inside the vessel 1 drops to a required value and oil level in the vessel 1 reaches the minimum level, the vessel 2 is loaded by a live vapor from condenser (valve Z-8 is open, while valve Z8 and Z9 are closed. Pressure inside the vessel 2 rises up to designed value

- Phase 3 - vessel 2 starts to work. Valve Z3 is opened and liquid agent (Ergolid) flows from vessel 2 to vessel 1 and drives a turbine.

-Phase 4 - vapor loading to vessel 1 - phase very similar to stage 2

\section{Dynamic oriented model of liquid piston engine}

The basic thermodynamic assumption for modeling a working agents behavior is the proper selection of the gas model. In the examined case, modeling the work of the system using the ideal gas model would be a huge mistake. Modeling the operation of the system required the use of a real gas model. Among the many available models [15], the Peng-Robinson model [16] was selected, which is characterized by a very good mapping of the transformation of organic compounds, especially 
in the area of phase transformations. This model, being a semi-empirical modification of the Van der Waals equation, is described by the basic dependence:

$$
p=\frac{R \cdot T}{V_{m}-b}-\frac{a \cdot a}{V_{m}+2 b \cdot V_{m}-b^{2}}
$$

Where,

coefficient which defines the intermolecular interactions:

$$
a=\frac{0.4572 \cdot R^{2} \cdot T_{\varepsilon}^{2}}{p_{c}}
$$

Coefficient which defines the volume of gas molecules:

$$
b=\frac{0,0778 \cdot \mathbb{R} \cdot T_{\varepsilon}}{p_{c}}
$$

$\alpha=(1+(0.37464+1.54226 \cdot \omega-0.269 ! 4$

$$
T_{r}=\frac{T}{T_{Q}}
$$

In general, the liquid piston engine consist of four main elements, which operation have to be simulated i.e.

-Vessels ( 1 \& 2) Vessels are used for the working agent expansion to force the flow of liquid through the turbine (see Fig 2). The key thermodynamic assumption is an adiabatic efficiency of expansion process that occurs inside the vessels. The dynamic model assumes the adiabatic efficiency is equal to $99 \%$. Due to the fact that adiabatic efficiency of expansion process in the vessel is greater that expansion in turbine (the adiabatic efficiency in turbine is within the range $80 \% . .90 \%$ ), the assumption seems to be resonable. Hence, it was assumed that heat transfer could be neglected. Vessels are simulated by the available in Aspen Hysys component "vessel" [15]. It requires to provide vessel geometry, the method of heat losses and definition of position of inlet and outlet port. The amount of liquid phase (Ergolid A) in the tank is determined by the height of the liquid column in $\%$ of the tank height. The geometric parameters used for simulations are shown in Table 2. It was assumed that there is no heat transfer between vessel and surrounding

-Expander - power generated by an oil expander is calculated based on the formula

$$
W=\frac{\left(p_{1}-p_{2}\right) \cdot \dot{m}}{\rho}
$$

where: p-pressure, bar; 1, 2-indices which denotes inlet and outlet, respectively; $\mathrm{m}$ - mass flow rate, $\mathrm{kg} / \mathrm{s} ; \rho$-density, $\mathrm{kg} / \mathrm{m}^{3}$.

The characteristic curves of the simulated oil expander are shown in Fig. 3

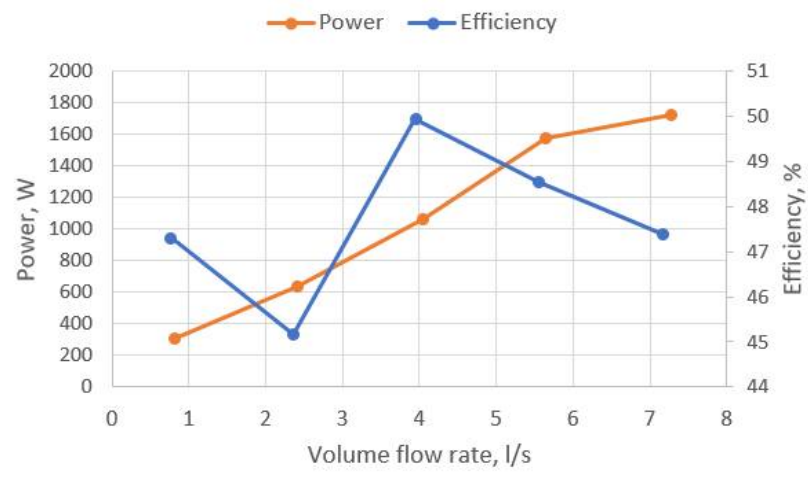

Fig 3: Characteristic curves of an expander operating on Ergolid

- Valves Valves are responsible for controlling the process of gas/liquid motion, hence the proper simulation of valves is a key element for accurate

\begin{tabular}{|c|c|}
\hline Property & Value \\
\hline Vessel orientation & $\begin{array}{l}\text { Vertical } \\
\text { cylinder* }\end{array}$ \\
\hline Geometry & Flat cylinder* \\
\hline Volume, m3 & $4 e-2$ \\
\hline Diameter, $\mathrm{m}$ & 0,3238 \\
\hline Height, $\mathrm{m}$ & 0,4857 \\
\hline $\begin{array}{l}\text { Location of nozzles for gas } \\
\text { inlet/outlet }\end{array}$ & $\begin{array}{l}\text { Top of the } \\
\text { vessel }\end{array}$ \\
\hline $\begin{array}{l}\text { Location of nozzles for oil } \\
\text { inlet/outlet }\end{array}$ & Vessel bottom \\
\hline $\begin{array}{l}\text { Volume occupied by a Ergolid at the } \\
\text { initial phase of expansion process, } \%\end{array}$ & 95 \\
\hline
\end{tabular}
modeling of system operation. Inside the valve, the isenthalpic throttling process occurs in order to obtain a designed flow rate or pressure difference.

Table 2 Vessels parameters used in Hysys

\subsection{Model validation}

The presented model was validated with experimental data. The comparison of experimental data against the model is presented in Figures $4-5$.

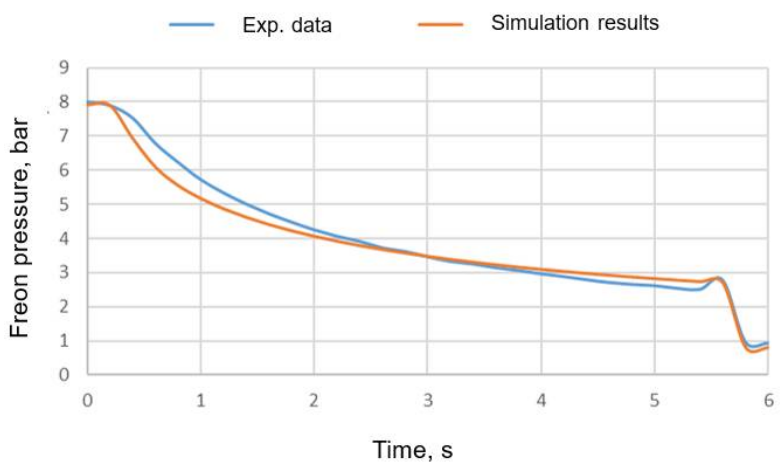


Fig 4: Comparison of simulated freon pressure and experimental data

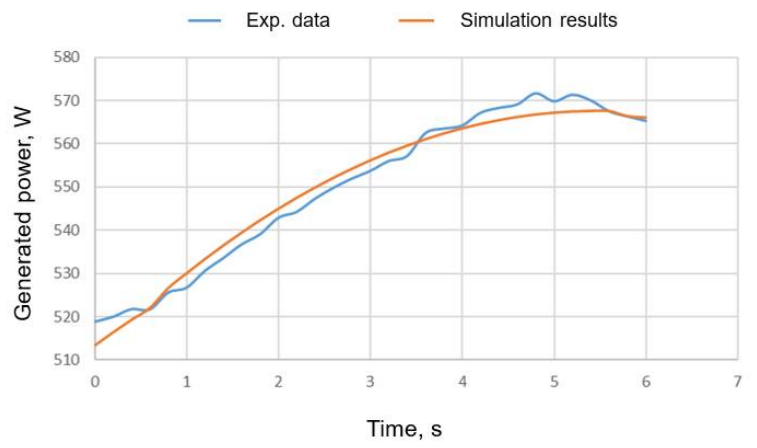

Fig 5: Comparison of experimental data against the model prediction

Figure 5 shows a comparison of measured power and model predictions. At $\mathrm{t}=0 \mathrm{~s}$ (the beginning of the cycle), the power is greater than 0 due to flywheel (mass of flywheel was $20,84 \mathrm{~kg}$ and moment of inertia was equal to $0,783 \mathrm{kgm} 2$ ), which is integrated with the expander. Model predicts power $511 \mathrm{~W}$ at time $\mathrm{t}=0 \mathrm{~s}$, while in the examined installation generated $520 \mathrm{~W}$. The maximum simulated power is $568 \mathrm{~W}$, while the real is slightly greater than $570 \mathrm{~W}$. The discrepancy is ca. $2 \%$.

\section{Results and discussion}

Nowadays, mathematical modeling is recognized as a basic method for analyzing novel concepts and most often a zero-dimensional approach is used for research on understanding novel cycles, hence Authors developed a fully-physical dynamic oriented model of a liquid piston engine that can aid in the evaluation of sensivity of numerous parameters for current operating conditions. A proposed model was implemented in Aspen Hysys modeling software and validated against experimental data. The comparison of experimental data against the simulation shows little discrepancy (ca. 2\%). It proves that the proposed model could be not only used a tool for better understanding the system operation but also as a tool for system optimization.

The preliminary simulations shows that the low grade waste heat conversion into electricity based on liquid piston engine is a promising area, however the detailed study are required to optimize the system operation with respect to operating conditions.

\section{Acknowledgments}

The authors would like to gratefully acknowledge the support from the the European Regional Development Fund under the Smart Growth Operational Programme 2014-2020 through the project "The innovative power plant equipped with liquid turbine and hydraulic-gas generator of working agent's flow, sourced by waste heat".

\section{References}

1. L. Donghyeon, C., Yujin and R., Jun-Hyung and L., In-Beum, INTERNATIONAL JOURNAL OF HYDROGEN ENERGY (2017), 25518-25530.

2. J. Kotowicz and L Bartela and K Dubiel-Jurgas, ARCHIVES OF THERMODYNAMICS (2017), 6587.

3. J. Kupecki, K Motylinski, M. Skrzypkiewicz, M Wierzbicki, and Y Naumovich, ARCHIVES OF THERMODYNAMICS (2017), 53-63.

4. L Szablowski, P Krawczyk, K Badyda, S Karellas, E Kakaras, \& W Bujalski (2017). Energy, 138, 1218.

5. Milewski, J., Badyda, K., \& Szabłowski, Ł. (2016). Journal of Power Technologies, 96(4), 245-260.

6. Reader, GT and Hooper, C,.: Stirling Engines, London: E. \& FN Spon (1983).

7. West, C,: The Fluidyne heat engine", Electronics and Applied Physics Division, Atomic Energy Research Establishment (1971).

8. Slavin, VS and Bakos, GC and Finnikov, KA, Applied energy Vol 86, Dec 2009, pp. 1162--1169.

9. Bakos, G and Slavin, VS and Finnikov, KA,., Patent of Russian Federation (2007).

10. S Narayan, A Gupta, and R Ranjeet Mechanical Testing and Diagnosis 5.2 (2015): 12.

11. A RUDOWICZ, Zbigniew; WASKIEWICZ, Jan; WOLOSZYNSKI, Wlodzimierz. Method and a system for driving a turbine. U.S. Patent Application No 15/114,855, 2016.

12. Bujalski, W., Futyma, K., Grzebielec, A., Milewski, J., Kucowski, J., Rudowicz, Z., Rusowicz, A. Analiza czynników niskowrzących do rozprężania w cylindrze z tłokiem hydraulicznym. Chłodnictwo: organ Naczelnej Organizacji Technicznej, 51, (2016)..

13. J Kajurek, A Grzebielec, W Bujalski, K Futyma, A Szczęśniak, A and Z Rudowicz,.: Wpływ właściwości czynnika roboczego na pracę organicznego obiegu Rankine'a, Rynek Energii (2017).

14. J Kajurek, A Rusowicz, A Grzebielec, W Bujalski, $\mathrm{K}$ Futyma, and Z Rudowicz,.: Wybór czynników chłodniczych dla zmodyfikowanego obiegu Rankine'a, Wydawnictwo Instytutu Techniki Cieplnej (2017).

15. HYSYS, ASPEN. 7.3 Manual. ASPEN TECH. 
16. Peng D-Y, Robinson DB. A new two-constant equation of state, Industrial \& Engineering Chemistry Fundamentals 1976;15(1):59-64. 